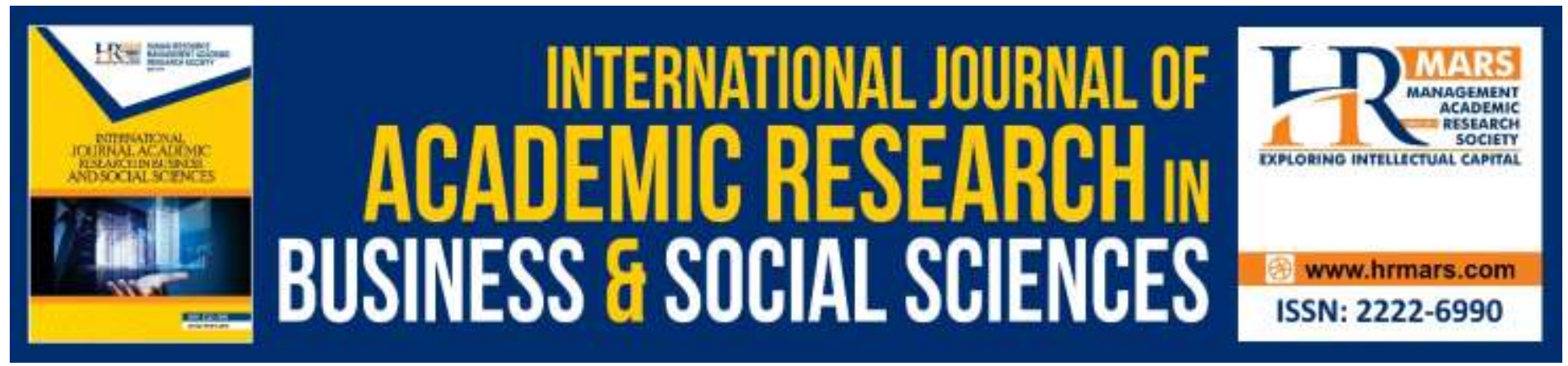

\title{
The Identity of Showmanship in Malay Musical Theatres
}

\author{
Muhammad Faisal, Syarul Azlina, Mardiana
}

To Link this Article: http://dx.doi.org/10.6007/IJARBSS/v9-i11/6638

DOI: 10.6007/IJARBSS/v9-i11/6638

Received: 12 November 2019, Revised: 25 November 2019, Accepted: 30 November 2019

Published Online: 03 December 2019

In-Text Citation: (Faisal, Azlina, \& Mardiana, 2019)

To Cite this Article: Faisal, M., Azlina, S., \& Mardiana. (2019). The Identity of Showmanship in Malay Musical Theatres. International Journal of Academic Research in Business and Social Sciences, 9(11), 1094-1104.

\section{Copyright: (C) 2019 The Author(s)}

Published by Human Resource Management Academic Research Society (www.hrmars.com)

This article is published under the Creative Commons Attribution (CC BY 4.0) license. Anyone may reproduce, distribute, translate and create derivative works of this article (for both commercial and non-commercial purposes), subject to full attribution to the original publication and authors. The full terms of this license may be seen

at: http://creativecommons.org/licences/by/4.0/legalcode

Vol. 9, No. 11, 2019, Pg. 1094 - 1104

http://hrmars.com/index.php/pages/detail/IJARBSS

JOURNAL HOMEPAGE

Full Terms \& Conditions of access and use can be found at http://hrmars.com/index.php/pages/detail/publication-ethics 


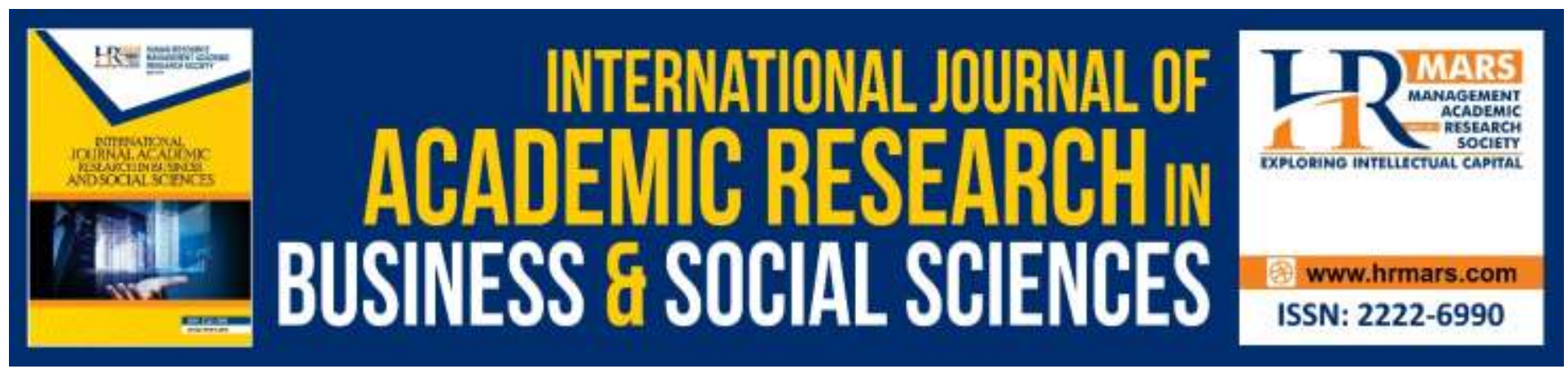

\title{
The Identity of Showmanship in Malay Musical Theatres
}

\author{
Muhammad Faisal, Syarul Azlina, Mardiana \\ Faculty of Music and Performing Arts, Sultan Idris Education University, Malaysia
}

\begin{abstract}
The touch of magic in performances is one of the observable 'wow-factor' elements through musical theatres. The uniqueness of portraying imagination into reality is a definite difference compared to the other types of theatre performances. The emergence of various Malay musical theatres specifically around the 21st century has displayed variations in their artistic depictions of showmanship following the creator's understanding and creativity. The showmanship in modern Malay musicals is overshadowed by Western characteristics which is Broadway. The struggle in glorifying Malay musical theatres surprisingly is inclined to follow the pattern shaped by the Westerns as the world's musical theatres pioneer. This research will disclose the formation of showmanship of Malay musical theatres as the identity of local work of arts based on several samples of staged performances in Istana Budaya, Kuala Lumpur. The questions on identity has become a debatable issue to look at the aspects that uplift it as local works of art. The formation of structure in delivering a showmanship combination between the director and the composer is also shown to gain conveyed influence through every touch in every work. Today, Malay musical theatres are shackled with questions on identity portrayal or are they basically mimicking the integrated form from Broadway. Referring to the structuring concept proposed by John Kenrick (2010), comparison of showmanship will be conducted to unwind the Broadway supremacy and the value of identity which can depict it as a Malay musical theatre. The results of this research contribute to the improvement of the performance's structure and illustrating the elements that uplift the identity of local works of art through the showmanship of Malay musical theatres as a reference for creators and academicians.
\end{abstract}

Keywords: Musical theatres, Malay Musical, Showmanship, Identity.

\section{Introduction}

The development of Malay musical theatres in Malaysia has successfully posed musical stream as one of the options available to the locals to watch in theatres. The ability to produce various musical theatre productions has elevated healthy competitions among activists and publishers. 
The variation in directing styles and patterns is portrayed with works containing different approaches and messages. Music, singing, acting and dancing are inseparable combinations in shaping a musical theatre. Ostwald (2005) emphasises that the basic quality of a musical theatre has to stress on the correct performance structures and the skills trained not on a restricted period of time as the mastery to theories and techniques is the foundation to a quality performance.

The history of the development of musical theatres in Malaysia has taken root for centuries through traditional theatres such as Makyong, Wayang Kulit, Main Puteri, Mek Mulung, Jikey, and Menora. The forms of these traditional theatres are the examples of traditional theatres containing the musical element and has rooted in Tanah Melayu since the 17th century. Most of those forms enliven the world of theatre performances through cultural heritage and ritual beliefs which originated from specific countries such as Indonesia and Thailand (Salleh, 2005). However, each showmanship has represented the identity of each state which is now being staged as a form of entertainment and education. Although they are formed in different states, the musical aspect is undoubtedly one of the must-have elements in performances until the forms transit to the era of nobles and drama.

Nobles has shaped a new showmanship in Malay theatrical performances. According to Salleh (2005), nobles are improvisation-based performance which dominate the structure of the whole play. Nobles too, do not involve any script as every portrayed act will be based on the summary of the story or the scenario produced by the director. Therefore, every actor and actress know only the storyline and characterisation, while everything else uses improvisation technique. Improvisation is not only applied in dialogues, but also implemented in physica motions such as silat movements, acting and cues. This aspect has indirectly been appealing the audience since it demands something unplanned and beyond expectations. Nobles stand on several elements such as the 'wow' factor, acting, languages, dancing, music and extra-turn. Singing and poetry are the medium building the musical element in nobles. Music is also seen as a support to background music while assisting the actors and actresses and the audience to be immersed in emotions.

\section{The Development of Malay Musical Theatres in the 21st Century}

The evolution of Malay musical theatres today is shaped based on the passage of time and thoughts. The 21st century has shown impressive development in the formation of musical theatres in Malaysia. Technological and infrastructure sophistication are able to produce gigantic productions which cost millions Malaysian Ringgit. Parallel to that, the effort in uplifting noble and traditional theatres has been put into motion relentlessly by applying construction elements, intended towards the new generations and tourism. Despite that, at the same time, theatre stages in the capital city are profusely enlivened with the staging of contemporary musical theatres which are being widely noticed and getting spectacular demand. 
Contemporary musical theatres phenomena started their outbreak after the staging of Ledang (2006), capturing the hearts of millions, prompting Enfiniti Production to stage Puteri Gunung Ledang season two in the same year and the third season in the year 2009 (Metro, 2014). Nevertheless, staged Malay musical theatres in international level stages such as Istana Budaya have started as early as in the year 1999. Majority of the staged Malay musical theatres in Istana Budaya in the 21st century focused more on biography and history-themed theatres.

Malay musical theatres portrayed in contemporary style are likely influenced by Broadway and West End. The Western touch in local works is as inseparable due to the birth of showmanship within Malay musical theatres evidently depicting popular cultures from lifestyle representations, social values, culture, apart from music and dancing. The Westernisation in local works can be seen more positively by improving the quality of performances, bearing the locals' taste and preferences in mind.

Works adapted from films and drama are also popular genres surounding the Malay musical theatres such as Maksima (2007), Cuci the Musical (2010), Cinta (2011), Baba (2012), Mengundang (2012), Cilok (2015), Cun (2015), and Dia Semanis Honey (2017). If Malay musical theatres are seen in contemporary context, surely they cannot be distinguished from the influence and approach formerly developed by Broadway and West End until they are known all over the world. Nonetheless, the identity of contemporary Malay musical theatres is not only seen from the structure, but also from the role of the musical theatre itself as a medium in shaping showmanship and mirroring the society.

\section{Challenges in Identity Formation in Malay Musical Theatres}

The growth in activities involving Malay musical theatres in Malaysia has always yearned for highquality performances. The quality of a performance is not only measured through the huge amount of cost consumed or sponsorship, but it is assessed through ideas, creativity and wide knowledge in musical theatres. The interpretation of local directors has brought forward the effort to create Malaysia-Broadway style, however, several of them failed to achieve good quality owing to the fact that the performance itself has clarified the element of singing while performing is sufficient to complete the structure of a musical theatre.

The disparity in forms of Malay theatres such as traditional theatres, nobles and drama also represent the identity of Malay theatres, but the context of this research focuses specifically on Malay musical theatres which have undergone evolution to more contemporary and modern forms. It is seen as having huge influence, taken from West musicals specifically Broadway and West End. Song composition, lyrics, singing styles, dancing and acting clearly portray popular elements taken into Malay musical performances especially staged productions around the 21st century. 
The first problem is seen through the understanding of the concept of musical itself. The term 'musical theatre' is less debatable in Malaysia since it is considered as a stream combining singing, acting and dancing only. Various perceptions and opinions are debatable in labelling whether the performances as attaining the musical stream or not. Based on the staged several Malay musical theatres, the director's interpretation towards musical theatres is like a display of a video clip onstage. The purpose and motive a song is created is ambiguous and it only fills the spaces between dialogues. It is noticeable when most of the scenes in a few Malay musical works offer discontinuation, and the performance delivered looks more like a concert.

The process of staging musical works varies from other theatrical works. Producing Broadwaystyle theatres press on song composition over plot arrangement. Musical book authors are liable for the formation of the whole musical structure in agreement with the composer and lyricist (Kenrick, 2010). In contrary, Malay musical theatres still depend on script production in particular with the formation of realism theatres. Consequently, songs will be inserted between dialogues in a musical to boost the function of the musical itself. Hence, the narrative structure is more developed through dialogues compared to the songs.

The difficulty in understanding the concept of a contemporary musical will contribute to the formation of the identity of Malay musical theatres itself. Elements comprised in Malay musical theatres are only seen through the language used and the actions from Malay actors and actresses. Act 160 (2) in The Federal Constitution of Malaysia has included three (3) criteria of a Malay individual - practises Islam, Malay cultural customs, and speaks Malay language (Ruslan, Mohd \& Zaini, 2010).

The issue on identity in performances is seen within a wider context since skeptical perceptions are often related to the contamination of culture and identity when Western influence is brought into local works. Entertainment is universal and is not subjected towards certain groups of individuals only. The purpose of a performance is to be staged, and can also be a platform to portray issues, messages and educational resources. Abdul Rahman Napiah (1987) has voiced out about the development of modern drama in Malaysia which includes modern-style Malay musical theatres, capable of being aforementioned medium but apprehension and comprehensiveness must be prioritised so that the staged performances are not produced poorly, but more structurised in a more quality musical style.

According to Kenrick (2010), the structure of performances in musical theatres is built through the character formation in singing conveyed by the characters. To identify the pattern of the structural formation of a musical theatre, Kenrick's concept will be applied in Malay musical theatres as a comparative analysis. Brown has stated that musical performances need to be structurised to at least the following two (2) categories: 


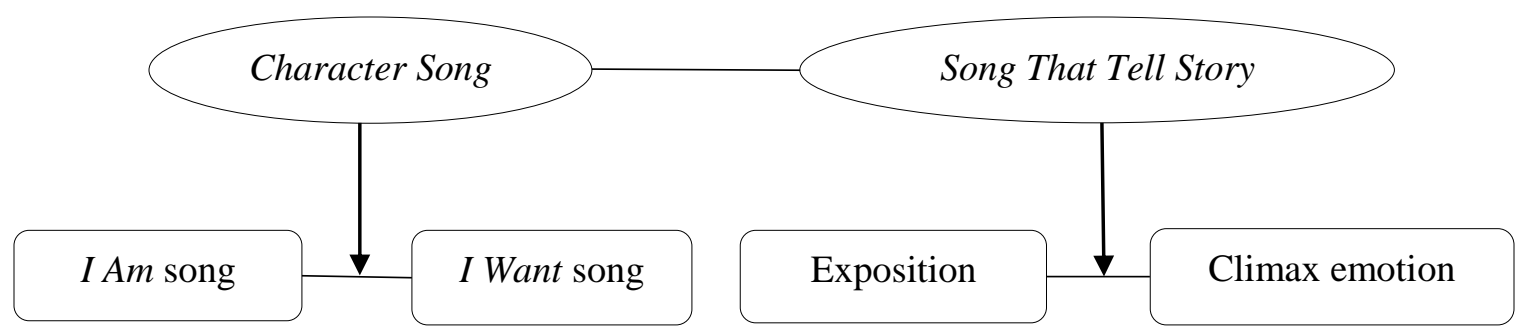

Figure 1.1: Character Song dan Song That Tell Story in the formation of musical theatre showmanship

The approach introduced by Kenrick (2010) combines character-building process in songs with delivery style that will shape the whole structure of a musical theatre performance. Based on the structural concept suggested by Kenrick, samples from several Malay musical theatres chosen are divided according to their plot arrangement. The comparison between Malay and Western musicals will be carried out to observe the influence of Broadway and director's approach towards local works. Every performed song illustrates the concepts used to bring forward character development and storyline themes. The identity of Malay musical theatres is seen through the function of songs in highlighting the cultural elements, social values and the potrayal of the locals' lifestyles. Malay musical theatre showmanship is based on the criteria in The Federal Constitution of Malaysia Act 160 (2) - staging the theatre in Malay language, practising Malay cultural customs and acted by Muslim actors and actresses even in the illustration of multicultural society as the representation of locals' cultural identity.

\section{Malay Musical Theatre Showmanship through Dramatic Songs}

In accordance to Malay musical theatres staged from the years 2000 until 2010, majority of the performances staged in Istana Budaya focused to repetitional themes such as history, biography and legends. The creation of each work is based on the script written through arranged plots similar to realism works. It is noticeable, from the performance style that presses more on dialogues than songs. Based on the listed themes, Sirah Junjungan manifested a different style by segregating acting and songs into certain segments. This style displays the influence of ancient Greece theatres which used choir as the storyteller in different segments (Brockett \& Hildy, 2006).

The concept highlighted through Sirah Junjungan is an interlude musical performend in the form of a concert. The story inserted with creative motions as the representation of emotion and situation in telling the story of Prophet Muhammad S.A.W has depicted the combination of acting, singing and dancing from different aspects. However, dialogues delivered did not use Arabic language, instead, Malay language was used with Mecca and Medina as the background set. Compared to other concepts which are more influenced by Broadway but showing similar 
INTERNATIONAL JOURNAL OF ACADEMIC RESEARCH IN BUSINESS AND SOCIAL SCIENCES

Vol. 9, No. 11, November, 2019, E-ISSN: 2222-6990 @ 2019 HRMARS

processes like realism works. The list below includes ten (10) Malay musical theatres staged with their highlighted themes:

Table 1: Staged Malay musical theatres in Istana Budaya around the years 2002-2010

\begin{tabular}{|l|l|l|l|}
\hline No. & Title & Year & Theme \\
\hline 1 & 23250 Bukit Kepong & 2002 & Historical \\
\hline 2 & Hang Li Po & 2004 & Historical \\
\hline 3 & Rubiah & 2005 & Historical /Biography \\
\hline 4 & Puteri Gunung Ledang & 2006 & Lagend \\
\hline 5 & Tan Cheng Lock & 2007 & Historical /Biography \\
\hline 6 & P. Ramlee the Musical & 2007 & Biography \\
\hline 7 & Patriot & 2008 & Historical \\
\hline 8 & Ibu Zain & 2008 & Historical /Biography \\
\hline 9 & Sirah Junjungan & 2008 & Historical /Biography \\
\hline 10 & Tun Abdul Razak & 2009 & Historical /Biography \\
\hline 11 & Mahsuri & 2009 & Lagend \\
\hline 12 & Tun Mahathir & 2010 & Historical /Biography \\
\hline
\end{tabular}

Character Song in Malay musical theatres still functions as the introduction for the characters and their characterisation. 23250 Bukit Kepong clearly introduced the identity of the citizens in Bukit Kepong through the song "Kami Bersaudara" which is included in the same category as the song I Am. The lyrics of the song are as follows:

Villagers

Hiduplah kami di kampunglah ini

Di sini kami mencari rezeki

Walaupun hanya penoreh getah

Hidup di sini dah lama

Sahabat kawan bagaikan saudara

Kami petani apa kurangnya

Inilah kampung maruah kami

Kerana kami bekorban

The lyrics of the song evidently explain about the villagers who were working as rubber tappers and farmers. The song also exposes the close-knit bond between the villagers and their willingness to sacrifice themselves to protect their village. In the next verse, there is a solo part from a Chinese character who sang with noticeable Chinese accent. The performance style in the Chinese character showed the illustration of the multicultural society in the village. Even though 
the character did not verbally explain about the cultural background, through the accent used through the singing clearly showed the I Am song was sung by a Chinese individual who mentioned his comfort in living multiracially.

Cuci the Musical also portrayed the song I Am in the exposition scene which included the four (4) main characters - Fairil, C'Tan, Jojo and Khai in the song "Cuci-cuci". The song I Am explained about their careers as building cleaners who lived in simplicity. Their occupation was also considered as lower class labour, but they too yearned of being successful. The first verse introduced C'Tan as a character who is afraid of heights.

Fairil

Cuci aku cuci dari pagi hingga senja nanti

Biar penat begini tapi aku puas hati

C'Tan:

Cuci aku cuci tinggi-tinggi jangan tinggi sangat

\section{Aku Ni Dah La Gayat Macam La Korang Tak Ingat}

The introduction concept in the song I Am is combined with the song I Want due to the fact that teh same song tells their dreams and hopes to obtain the opportunity of cleaning the Kuala Lumpur City Center (KLCC) because that chance is deemed as profitable to them. Lyrics mentioning KLCC also illustrate the identity of KLCC as Malaysia's identity and the country's prideful landmark.

Fairil, C'Tan, Jojo \& Khai:

Kami tak kisah

Apalah esok menanti

Kami pastikan kaya

Seperti Dato dan Tan Sri

Kami tak kisah

Asalkan Impian Kami

Semestinya Menjadi

Kami Cuci KLCC

The introduction of characters mentioned in the examples above is influenced by Broadway-style performance structure since the characters were introduced in the first scene through certain songs. However, some Malay musical theatres did not use the song I Am in their perfomances such as Puteri Gunung Ledang since it tells the story of a famous legendary character. Character introduction was not displayed, but it emphasised more on the goal and desire through the song I Want. Some of the lyrics were from the song "Moga Temui Cinta" to convey their wishes in prayers so they could get a lover.

Gusti Putri:

Maha pencipta sambutlah harapan dan doa 


\section{Takdirkanlah}

Hamba ini ingin dicintai

The concept of introducing oneself and stating dreams through songs are the styles that contribute to the formation of modern musical structures. Malay musical theatres showcase a more plot-dominated structure compared to songs. The story of a situation is revealed through spoken dialogues. However, most Character Songs in Malay musical theatres are put into songs so they can be conveyed simply and comprehensively.

The story of tales and events combined in a song function to display the unrevealed occurrences on the stage. This concept which is introduced in Broadway is also portrayed in several Malay musical theatres. The song "Tujuh Syarat" in Puteri Gunung Ledang clearly tells the seven (7) conditions given by Gusti Putri to the Sultan of Malacca to marry her. The telling of the seven (7) conditions was delivered in the form of exposition by the ensemble line. It also gives dramatic effects for the scene. The showmanship portrayed also focuses on artistic elements which showcase the Gusti Putri's character as someone who wants to test the Sultan of Malacca. The arrangement of exposition in the second segment has impacted the structurised conflict before reaching the climax of the story. The content of the song also exhibits Royal languages as the intermediary language as the representation of the royalty.

Tun Abdul Razak The Musical also uses exposition song as the summary of the story through the song "Kita Serumpun". The song has completed the structure of the first segment to illustrate the unity between Malaysia and Indonesia. The function of the song "Kita Serumpun" is to promote understanding between the two countries to avoid any unwanted confrontation. Apart from functioning as an illustrated summarisation for unity, it also represents the identity of the society through the conveyed lyrics.most of the songs in Tun Abdul Razak highlighted patriotism and unity among all races. Songs such as "Enjit-enjit Semut", "Rakyat Bersatu". "Jangan Merdeka Didustai" and "Merdeka Malaya" are flexible songs which can be organised according to dramatic plots. The content of the lyrics in the songs have more impact to patriotism compared to the emotions displayed when the characters are singing. Despite that, the structure of showmanship emphasises on the dialogues over songs.

\section{Conclusion}

The identity of Malay musical theatres in the modern performance context is more inclined to the content compared to the organisation of a musical theatre. The portrayal of culture, speech, social values in the society showcase the characteristics of a Malay musical. Roughly, Malay musical theatres' showmanship is heavily influenced by West End and Broadway styles, but Malay musical theatres stress more on dialogues than songs, putting songs as emotional or situation support over the role of the songs as storytellers in a structure shaped by Western musicals. Nevertheless, the stabilisation of the structure can boost the performance of Malay musicals if the songs are prioritised to put forward musical theatres. 
Local activists are passionate in producing praiseworthy Malay musical works. However, artistic creations are sometimes able to deter the function of theatres as an educational platform. Mimicking Broadway style cannot shape a Malay musical theatre since the process determines the quality of a modern musical. Thus, the effort put forth by researchers needs to be supported by all so that Malay musical theatres are on the right track. Researchers and creators must work side by side to create more quality products that can be not only be staged for local but also for global audiences to know Malay musical theatres in universal contexts.

Broadway and West End musical performances that have been a precursor to develop world musical theater have often served as the benchmark for modern musical theater formation. It also creates a process that can serve as a guide to create a production journey that balances narrative, acting, music and dance. Exposure to produce a musical theater can be channeled through a number of mediums such as festivals, workshops, seminars, forums, conferences, and through apply education systems especially at school and tertiary institutions for courses related to the performing arts. The role is combine knowledge led by academics, researchers, activists and musical theater professionals who are capable of disseminating information according to relevant fields of ability.

\section{Acknowledgement}

Deep appreciation and gratification for several individuals involved in data contribution throughout the process of this research such as Dr Mumtaz Begum PV Aboo Backer and Dr Abdul Razak Abdul Aziz from Universiti Sains Malaysia, Encik Shapee bin Che Embii as the Deputy Director of National Department for Culture and Arts, Sarawak, and Prof Dr Hatta Azad Khan who helped in completing this research.

\section{Corresponding Author}

Muhammad Faisal bin Ahmad

Faculty of Music and Performing Arts

Sultan Idris Education University

35900 Tanjong Malim

Perak, Malaysia

mfaisal@fmsp.upsi.edu.my

\section{References}

Abdullah, N. A. V. (2011). Ulasan pementasan: 'Muzikal Tun Mahathir' musim pertama. Wacana Seni Journal of Arts Discourse. (10). 99-109. http://wacanaseni.usm.my/w_j_10.htm

Bordman, G. (2001). American musical theatre: a chronical. United Kingdom; Oxford University Press

Brockett, O. G., \& Hildy, F. J. (2006). History of the theatre. New York: Pearson

Brown, L. A. (2007). The integration of music and lyrics with the book in the american musical. 
INTERNATIONAL JOURNAL OF ACADEMIC RESEARCH IN BUSINESS AND SOCIAL SCIENCES

Vol. 9, No. 11, November, 2019, E-ISSN: 2222-6990 ㄷ 2019 HRMARS

(Spurrier, J. Ed). United State: Southern Illinois University

Brown, L. A. (2007). The dramatic function of songs in musical theatre. Diambil daripada http://larryavisbrown.homestead.com/files/theater_topics/musical_

Dorothy, C. V. (1997). Structure, genre \& textuality integrity. United Kingdom: Sheffield Academic Press

Kenrick, J. (2010) Musical theatre: a history. United States: University of Michigan.

Khan, H. A. (2014). Four musical theatres. Kuala Lumpur; Institut Terjemahan \& Buku Malaysia.

Napiah, A. R. (2017). Drama nusantara kajian bandingan sejarah dan kritikan. Kuala Lumpur: Dewan Bahasa dan Pustaka.

Napiah, A. R. (1987). Drama moden malaysia: perkembangan dan pertumbuhan. Kuala Lumpur: Dewan Bahasa dan Pustaka.

Ostwald, D. S. (2005). Acting for singers: creating believable singing characters. New York: Oxford University Press.

Salleh, A. S. (2005). Aspek lakonan dalam teater bangsawan. Kuala Lumpur: Jabatan Kebudayaan dan Kesenian Negara.

Zainuddin, R., Ismail, M. M., \& Othmam, Z. (2010). Kenegaraan malaysia edisi kedua. Kuala Lumpur: Oxford Fajar Sdn. Bhd. 